Maurice A. Deane School of Law at Hofstra University Scholarly Commons at Hofstra Law

Hofstra Law Faculty Scholarship

$10-2012$

\title{
Ethical Advocacy for Immigrant Survivors of Family Crisis
}

Theo Liebmann

Maurice A. Deane School of Law at Hofstra University

Follow this and additional works at: https://scholarlycommons.law.hofstra.edu/faculty_scholarship

\section{Recommended Citation}

Theo Liebmann, Ethical Advocacy for Immigrant Survivors of Family Crisis, 50 Fam. Ct. Rev. 650 (2012)

Available at: https://scholarlycommons.law.hofstra.edu/faculty_scholarship/742

This Article is brought to you for free and open access by Scholarly Commons at Hofstra Law. It has been accepted for inclusion in Hofstra Law Faculty Scholarship by an authorized administrator of Scholarly Commons at Hofstra Law. For more information, please contact lawcls@hofstra.edu. 
Title:

Collateral Immigration Benefits and Ethical Advocacy in Family Court Proceedings

\title{
Author:
}

Theo Liebmann*

\begin{abstract}
:
The involvement of family courts in the lives of youth and families creates significant opportunities for advocates to assist their clients with immigration-related issues. Informed and effective advocacy on these issues in family court can make life-changing, and even life-saving, differences. More specifically, immigration issues are germane to family court because certain vital avenues of immigration relief available to survivors of abuse, neglect, abandonment and other forms of family crisis explicitly depend on findings, orders, and certifications that are issued in the context of family court proceedings. After describing these forms of relief, and the family court's role in immigrants' access to them, this essay analyzes how ethical mandates related to client counseling, representational goals, and competence require family court practitioners to provide advice and advocacy related to these collateral benefits to family court proceedings.
\end{abstract}

\section{Introduction}

Immigration laws and family court proceedings are intertwined in complex and significant ways. ${ }^{1}$ Most often, their interaction has led to harsh outcomes for immigrant families, including a growing number of deportations which separate families and lead to permanent terminations of parental rights ${ }^{2}$ the placement of thousands of children in foster care because their parents have been detained by federal immigration authorities ${ }^{3}$ and the heightened risk faced by immigrant survivors of domestic violence of losing their children due to both detention and deportation. ${ }^{4}$ In

\footnotetext{
* Theo Liebmann is a Professor of Clinical Law and Director of Clinical Programs at the Maurice A. Deane School of Law at Hofstra University School of Law, where he is Attorney-in-Charge of the Hofstra Child Advocacy Clinic.

${ }^{1}$ See David B. Thronson \& Frank P. Sullivan, Family Courts and Immigration Status, 63 JUV. \& FAM. CT. REV. 1 (2012)(providing overview of significant ways in which immigration status and family court matters overlap, and proposing principles for when family courts should engage in immigration issues).

${ }^{2}$ See generally Seth Wessler, SHATTERED FAMILIES: THE PERILOUS INTERSECTION OF IMMIGRATION ENFORCEMENT AND THE CHILD WELFARE SYSTEM (Applied Research Center 2011)(reporting, inter alia, that in the six months between January and June of 2011, over 46,000 parents of U.S. citizens were deported).

${ }^{3}$ ID. at 4 . If that same rate holds true for new cases, in the next five years there will be at least 15,000 more such children entering foster care. ID.

${ }^{4}$ ID. These issues are national in scope; more than one in four cases involving foster children with detained or deported parents were from non-border states. ID. Many immigrant survivors of domestic violence are forced to choose between remaining with an abuser, or reporting the abuse and risking detention and the loss of their children. See, e.g., Leslye E.
} 
addition, pleas and admissions in abuse, neglect, delinquency, and domestic violence cases in family court carry with them potential collateral consequences for immigrants, such as permanent geographical separation from their homes and families, with which non-immigrants need not contend..$^{5}$

But while the interplay of immigration laws and family court matters can create devastating outcomes for parents and children, it also can create significant opportunities. Three forms of immigration relief in particular are explicitly available to immigrant survivors of family crisis ${ }^{6}$ who find themselves in family courts, making that court an exceptional pathway to permanent legal status: (1) Special Immigration Juvenile (SIJ) Status, which benefits youth who have been abused, neglected, abandoned or similarly maltreated or deserted by one or both parents; (2) the Violence Against Women Act (VAWA), which benefits youth and adults who are the victims of domestic violence; and, (3) the U visa, which benefits youth and adults who are victims of criminal activity and cooperate with the investigation and prosecution of that activity by law enforcement or child protection services. These forms of relief are among the few explicit methods through which survivors of family crisis can seek legal permanent residence, ${ }^{7}$ and by the most conservative estimates they affect tens of thousands of immigrants each year. ${ }^{8}$

Orloff, et al., With No Place to Turn: Improving Legal Advocacy for Battered Women, 29 FAM. L. Q. 313 (1995)(describing some of the unique difficulties faced by unauthorized immigrant women who are survivors of domestic violence).

${ }^{5}$ See Theo Liebmann, Family Court and the Unique Needs of Children and Families Who Lack Immigration Status, 40 Colum. J.L. \& Soc. Probs. 583, 593-598 (2007)(providing an overview of collateral immigration consequences to admissions in family court proceedings).

${ }^{6}$ Because different jurisdictions use different terminology for abuse, neglect, dependency, abandonment, maltreatment, terminations of parental rights, as well as for voluntary surrenders of guardianship or custodial rights, this essay will use the term "family crisis" to cover matters involving voluntary or involuntary involvement by the family court to help families and children achieve safety and permanency.

${ }^{7}$ Other basic family-based forms of immigration relief may also be available if a survivor otherwise qualifies, but they are not explicitly designed to assist survivors of family crisis.

${ }^{8}$ Legal permanent residence is available to a maximum of 10,000 U visa applicants and unlimited VAWA applicants per year. See "New Classification for Victims of Criminal Activity; Eligibility for 'U' Nonimmigrant Status" 72 Fed. Reg. 53014 (Sept. 17, 2007)(limiting U visa applications to 10,000). Another approximately 1600 youth obtained 
The immigration law aspects of these forms of relief can be complex, and in certain areas are still unsettled. Yet each of these pathways clearly relies on basic findings which can be procured only in family courts, or to which family courts provide relatively simple access. The substance of these findings and their ultimate affect on family stability are manifestly consistent with the core family court goal of supporting safety, well-being and permanency for children and families. Informed and effective advocacy by practitioners can therefore offer immigrant clients a critical opportunity to obtain these necessary pre-requisite findings and adjust their immigration status, as well as to advance important objectives of family court proceedings. Unfortunately, the extent to which family court lawyers inform their clients on the availability of those findings, and subsequently advocate to procure them, is erratic and inconsistent both within and across different jurisdictions. ${ }^{9}$

This essay describes why those lawyers who fail to advise and advocate regarding prerequisite findings are not only missing an opportunity to assist their clients in vital ways, but are also violating ethical rules. The essay first briefly describes the general extent to which lawyers are ethically mandated to pursue legal benefits for clients that are collateral to the primary scope of representation, but still related to ultimate representational goals and crucial rights of clients. ${ }^{10}$

adjusted to permanent legal status in 2011. DEPT. OF HOMELAND SECURITY, YEARBOOK OF IMMIGRATION STATISTICS: 2011, TABLE 7, available at http://www.dhs.gov/files/statistics/publications/LPR11.shtm.

${ }^{9}$ See generally Randi Mandelbaum \& Elissa Steglich, Disparate Outcomes: The Quest for Uniform Treatment of Immigrant Children, __ FAM. CT. REV. __ (2012).

10 There is some disagreement of the definition of "collateral" in context of collateral consequences of criminal convictions, which is where the term is used most frequently. See Jenny Roberts, The Mythical Divide Between Collateral and Direct Consequences of Criminal Convictions: Involuntary Commitment of "Sexually Violent Predators, " 93 MINN. L. REV. 670, 689-93 (2008)(describing and critiquing the three main tests and listing cases relying upon them). Roberts notes that the prevailing definition of "direct consequence" comes from the Fourth Circuit. See Cuthrell v. Dir., Patuxent Inst., 475 F.2d 1364, 1366 (4th Cir. 1973) ("The distinction between 'direct' and 'collateral' consequences of a plea, while sometimes shaded in the relevant decisions, turns on whether the result represents a definite, immediate and largely automatic effect on the range of the defendant's punishment."). For purposes here, collateral is used in the more general sense to mean secondary to the primary legal issue of the case. See BLACK’S LAW DICTIONARY 79 ( $3^{\text {rd }}$ ed. 1991). 
After then describing the ways that access to SIJ status, VAWA and U visas depend on findings issued in family court, the essay demonstrates why pursuing those findings when available is within the ethically mandated scope of representation in family court proceedings.

\section{The Ethical Duty to Represent Clients on "Collateral” Issues}

Lawyers have a clearly articulated duty to advise clients and zealously advocate on their behalf that extends to certain collateral legal issues that are beyond the primary scope of representation. The extent of this duty is proscribed by the two pillars of a client-centered legal system: the duty to provide sufficiently thorough counseling to enable clients to make informed decisions about the goals of the representation; ${ }^{11}$ and the duty to pursue those goals zealously. ${ }^{12}$

Lawyers have a fundamental duty to counsel their clients to the extent reasonably necessary for the client to make informed decisions regarding the representation. ${ }^{13}$ A thoroughly counseled client has an understanding of her rights and obligations, and therefore is generally able to participate intelligently in the matter. ${ }^{14}$ The objective of the representation is the most significant decision a client makes. ${ }^{15}$ It is the prerogative of the client to set the goals of the representation; and the duty of the lawyer to provide information and counseling regarding that decision, ${ }^{16}$ and to zealously seek to achieve the client's goals. ${ }^{17}$ The objectives, as determined by the client, serve as

\footnotetext{
${ }^{11}$ Model Rules of Prof'l Conduct Preamble: A Lawyer's Responsibilities Par. 2, Rs.1.4 \& 2.1 (1983).

12 MOdel RUles PREAMBle: A LAWYER's RESPONSIBILITIES PAR. 2.

${ }^{13}$ MODEL RULES, supra note 11, R. 1.4.

${ }^{14}$ ID. PREAMBLE, PAR. 1; R. 1.4(b); R. 1.4 cmt. 1.

${ }^{15}$ ID. R. 1.4 cmt. 5; R 1.2(a)(requiring a lawyer to abide by a client's decisions concerning the objectives of representation); R. $1.2 \mathrm{cmt} .1$.

${ }^{16}$ Restatement (ThiRd) OF LAW Governing LaWyers $§ 16(1)(2000)$; Monroe Freedman \& Abbe Smith, Understanding Legal ETHICS 65 ( $4^{\text {th }}$ ed. 2010). That prerogative does have limitations. See ModEL RulES, supra note 11, R. 1.2.

${ }^{17}$ Model Rules, supra note 11, PREAMBLE. Again, this prerogative has several limitations, some of which are discussed infra.
} 
the primary guidepost for a lawyer's actions throughout the client-lawyer relationship. ${ }^{18}$

The client's prerogative is not unlimited, but it is notably broad. Courts and ethics review boards have made clear that matters requiring the lawyer to advise the client include those where the counseling involves issues of substantive law that are distinct from the original focus of the representation ${ }^{19}$ and where counseling involves "real-world" consequences of various possible objectives of representation. ${ }^{20}$ Most significantly, the lawyer also must pursue any legitimate client objective that directly affects the ultimate resolution of the case or the substantive rights of the client. $^{21}$ Even where a possible objective involves a different area of law from the underlying case, then, clients are entitled to counseling and advocacy if that possible objective impacts either how the underlying case is resolved, or affects a substantive right of the client.

The inquiry in the context of the duty of lawyers representing immigrant survivors in family court is therefore the following: whether procuring findings that are vital to obtaining immigration relief, in the course of representing a client in a family court matter, constitutes an objective that directly affects either a substantive right of the client or the ultimate resolution of the case. If so, then lawyers for immigrant survivors have an ethical duty to advise their clients of this possible objective of the representation, and then pursue that objective if the client wishes. Before addressing that question, this essay examines more closely SIJ, VAWA and U visas, and how each relates to family court proceedings.

\footnotetext{
${ }^{18}$ MODEL RULES, supra note 11, R. 1.2(a).

${ }^{19}$ Matter of Disciplinary Proceedings Against Winkel, 217 Wis.2d 339, 344, 577 N.W.2d 9, 11 (Wis. 1998)(lawyer in business transaction should have explained risk of criminal prosecution to client associated with surrender of business assets to bank).

${ }^{20}$ Ariz. Eth. Op. 97-6 (Sept. 8, 1997)(criminal defense attorney must advise client of real-world consequences of entering into cooperation agreement with law enforcement.)

${ }^{21}$ Ellen J. Bennett Et Al., Annotated Model Rules of Professional Conduct 32 (7 $7^{\text {th }}$ ed. 2011).
} 


\section{Forms of Immigration Relief Where Family Court Findings Play a Vital Role}

As mentioned above, there are three forms of relief that are explicitly available to immigrant survivors of family crisis who find themselves in family courts - Special Immigrant Juvenile Status, VAWA, and U visas. Each can provide these immigrants with an avenue to permanent legal status, and each depends on findings that are either issued only in family courts, or are routinely accessible in family court matters.

\section{a. Special Immigrant Juvenile Status}

Special Immigrant Juvenile ("SIJ") Status derives from a section in the Immigration and Naturalization Act that provides a pathway to permanent legal status for abused and neglected children under $21 .^{22}$ This remarkably compassionate federal provision, enacted in 1990, allows an immigrant youth to petition for status as a permanent legal resident so long as she meets certain criteria. SIJ status has understandably been embraced by many immigration and family lawyers around the country as the best hope to normalize the lives of youth confronting the challenges of both abusive and neglectful parents, as well as harsh governmental treatment of illegal immigrants. $^{23}$

Family courts play a major role in enabling children to obtain SIJ status. While the SIJ petition itself must be brought with the federal Citizenship and Immigration Services agency (“CIS"), these petitions cannot be brought until a state family court has made an order containing what the federal statute refers to as "special findings." 24 These findings concern

${ }^{22}$ Immigration and Nationality Act §101(a)(27)(J), 8 U.S.C. § 1101(a)(27)(J) (2006), 8 C.F.R. §204.11(a).

${ }^{23}$ See, e.g., Michelle Abarca et al., No Abused, Abandoned, or Neglected Child Left Behind: Overcoming Barriers facing Special Immigrant Juveniles, in AMERICAN IMMIGRATION LAWYERS ASSOCIATION IMMIGRATION \& NATIONALiTy LAW HANDBOOK 520 (2007-08); Anne Chandler, et al., The ABCs of Working With Immigrant Children to Obtain Special Immigrant Juvenile Status for Those Abused Neglected or Abandoned, in AMERICAN IMMIGRATION LAWYERS ASSOCIATION IMMIGRATION \& NATIONALITY LAW HANDBOOK 308 (2006-2007).

${ }^{24}$ Immigration and Nationality Act §101(a)(27)(J), 8 U.S.C. § 1101(a)(27)(J) (2006), 8 C.F.R. §204.11(a). 
matters and standards within the traditional purview of family courts: dependency; familial reunification; abuse, neglect and abandonment; and best interests. More specifically, SIJ status requires three explicit findings from the family court: that the immigrant youth is dependent on the family court; ${ }^{25}$ that reunification of the immigrant youth with one or both parents is not a viable option due to abuse, neglect, abandonment or a similar basis,${ }^{26}$ and that it is not in the best interest of the immigrant youth to be returned to her country of origin. ${ }^{27}$ Family courts play no role in the final determination of the child's immigration status; that decision remains solely within the power of CIS. The special findings, however, which may only be made by a family court, ${ }^{28}$ are an indispensible facet of the application of SIJ status - without them, CIS cannot grant permanent legal status to the child.

\section{b. VAWA Petitions}

When Congress enacted the Violence Against Women Act (VAWA) in 1994, it became the first piece of federal legislation with the explicit goal of addressing domestic violence. ${ }^{29}$ VAWA both strengthened the protections available to battered women, and increased the level of cooperation between services for battered women and the criminal and civil justice systems. One of the primary problems that VAWA was intended to address was the use of immigration laws by abusers to exert control over their spouses. The immigration status of many non-citizens depends on their relationship to their spouses. Prior to the enactment of VAWA, victims of domestic abuse

\footnotetext{
25 8 C.F.R. $\$ 204.11(\mathrm{c})(3)$.

268 C.F.R. $\$ 204.11$ (a), (c)(5). New regulations which would more accurately reflect statutory changes made in 2008 have been proposed, but have not yet been adopted. "Proposed Rules" 76 Fed. Reg. 172 (Sept. 6, 2011).

278 C.F.R. $\$ 204.11(\mathrm{c})(6)$. Findings as to the age and marital status must also be made, but need to be made by the Family Court.

28 C.F.R. $\$ 204.11(\mathrm{a})$.

${ }^{29}$ Violent Crime Control and Law Enforcement Act of 1994, Pub. L. No. 103-322, §§40001-702, 108 Stat. $1796,1902-$ 55 (1994).
} 
were regularly deterred from taking action because of the fear of being deported, and because abusers could use immigration laws to threaten and control spouses and children. ${ }^{30}$ Congress sought to remedy this problem by creating a pathway to lawful permanent residence for survivors of domestic abuse, including abused spouses, abused children, and abused parents, that does not require cooperation from the abuser. Under VAWA, eligible abuse survivors can file their own petitions for lawful permanent residence without any participation of the abuser, and indeed without having to disclose the petition to the abuser at all. Once these petitions are submitted with the required supplemental forms and documents, the petitioners are interviewed by an immigration official to determine admissibility as a lawful permanent resident.

A VAWA self-petitioner must satisfy seven requirements to establish eligibility: (1) relationship to the abuser; (2) that the abuser is a U.S. citizen or lawful permanent resident; (3) that the petitioner resides in the United States (though there are exceptions to this); (4) that the petitioner does, or at one time did, reside with the abuser; (5) credible evidence of battery or extreme cruelty; (6) good moral character; and (7) that the petitioner married the abuser in good faith, and not for the purpose of evading immigration laws. ${ }^{31}$ It is in the fifth of these requirements - credible evidence of battery or extreme cruelty - where family court involvement can provide essential findings. "Credible evidence of battery or extreme cruelty" can include the type of restraining orders and civil protection orders that are frequently sought, and issued, in family offense and child dependence proceedings in family court. ${ }^{32}$ In fact, such orders are generally considered among the most convincing types of evidentiary proof that can be offered, and non-citizens who obtain

\footnotetext{
${ }^{30}$ H.R. REP. No. 103-395 at 26-27 (1993).

${ }^{31}$ Moira Praeda et al., Preparing the VAWA Self-petition and Applying for Residence, in EMPOWERING SURVIVORS: LEGAL RIGHTS OF IMMIGRANT VICTIMS OF SEXUAL ASSAULT (2009), available at http://iwp.legalmomentum.org/reference/manuals/sexual-assault.

${ }^{32}$ EMPOWERING SURVIVORS, supra note 20, at 20.
} 
protection orders have established one of the most important elements of the VAWA self-petition. Such orders can serve as critical support for the non-citizen's claim of battery or extreme cruelty, and can confirm the credibility of the self-petitioner.

\section{c. U Visas}

The $\mathrm{U}$ visa is a form of immigration relief through which undocumented victims of certain crimes can become eligible for permanent legal status by cooperating with the investigation or prosecution of those crimes. Congress created the U visa in 2000 to encourage unauthorized ${ }^{33}$ crime victims to cooperate with law enforcement without fear of deportation, ${ }^{34}$ and to provide one of the few forms of humanitarian immigration relief available to victims of crimes committed in the United States. $^{35}$

To establish eligibility for a U visa, a person must show that she suffered substantial physical or mental abuse due to being a victim of one of certain enumerated criminal activities committed in the United States; that she possesses information concerning the criminal activity; and that she has obtained a certification from a law enforcement official, prosecutor, judge, immigration official or other federal or state authority that she is being, has been or is likely to be helpful to a federal, state or local investigation or prosecution of one of the enumerated criminal activities. ${ }^{36}$ Eligible criminal activity includes rape, incest, domestic violence, sexual assault, abusive sexual contact and felonious assault, all of which frequently lead to concurrent proceedings in criminal

\footnotetext{
${ }^{33}$ The term "unauthorized" is used throughout this essay, instead of the terms "illegal" or "undocumented," as a more accurate reflection of the status of immigrants who are in the U.S. without authorization. See, e.g., Jeffrey Passel, Unauthorized Migrants in the United States: Estimates, Methods, and Characteristics, OECD Social, Employment and Migration Working Papers, No. 57, OECD Publishing (2007).

34 8 CFR § 214.14.

${ }^{35}$ Trafficking Victims Protection Act of 2000, Pub. L. No. 106-386, 114 Stat. 1464 (2000). The U visa is incorporated in the section of the TVPA referred to as the Battered Immigrant Women Protection Act of 2000, Pub. L. No. 106-386, 114 Stat. 1518 (2000).

${ }^{36}$ INA Sec. 101(a)(15)(U)(i)(1); 8 U.S.C. Sec. 1101(a)(15)(U)(i)(1).
} 
court and family court. In fact, because the standard of proof is generally lower in family courts than in criminal courts, cases related to such incidents are at times only brought in family court, so obtaining appropriate family court findings can be critical to proving eligibility for a U visa.

The regulations define "victim" broadly to include those who are directly harmed by the criminal activity, as well as those who are bystanders but are harmed during the commission of the act. ${ }^{37}$ In addition, where the primary victim is deceased, incompetent or incapacitated, the spouse, children, ${ }^{38}$ parents ${ }^{39}$ and siblings ${ }^{40}$ of a victim may qualify for a U visa. Such family members can also receive $U$ visas if they can show that receipt of the visa is necessary to avoid undue hardship, or if a government official certifies that the investigation or prosecution would suffer without the assistance of the family member. ${ }^{41}$ While $\mathrm{U}$ visa applicants must prove that they possess information about the criminal activity, those under 16 when the activity occurred, or who lack sufficient capacity, do not have to prove they possess the information if a parent, guardian or "next friend" possesses the information. ${ }^{42}$

All $\mathrm{U}$ visa applicants must provide a certification that the applicant has been, is being, or is likely to be helpful, and that the applicant is a victim of one of the qualifying criminal activities. ${ }^{43}$ The agencies and individuals eligible to sign the certification include: federal, state, and local judges; federal, state and local law enforcement agencies; federal, state and local prosecutors; and even child protective services agencies. ${ }^{44}$ Because one of the congressional goals in enacting the $\mathrm{U}$

\footnotetext{
378 C.F.R. $\$ 214.14(\mathrm{a})(9)$ and (14).

${ }^{38}$ Children are eligible if they are under 21. 8 C.F.R. $\S 214.14(a)(14)(i)$

${ }^{39}$ Parents are eligible if the direct victim is under 21 . Id.

${ }^{40}$ Siblings are eligible if the direct victim is under 21 and the siblings are under 18 . Id.

${ }^{41}$ INA $\S 101(\mathrm{a})(15)(\mathrm{U})(\mathrm{ii}) ; 8$ U.S.C. $\$ 1101(\mathrm{a})(15)(\mathrm{u})(\mathrm{ii})$.

428 C.F.R. $\$ 214.14$ (b)(2). A next friend is a person who acts in a legal proceeding on behalf of an individual who is incompetent or incapacitated. Id. at (a)(7).

438 C.F.R. \$214.14(c)(2)(i); the certification form that must be filled out and signed is available on the CIS website at http://www.uscis.gov/portal/site/uscis/.

44 8 C.F.R. $\$ 214.14(\mathrm{a})(2)$.
} 
visa provision is to encourage victims to come forward and report their crimes, $U$ visas are available even if the victim does not actually serve as a witness, and even if the investigation does not lead to criminal prosecution. Especially for victims who have not had contact with law enforcement or a prosecutor, family court may be the only venue where a victim can receive the necessary certification, either through a judge or an agency such as child protection services. The certifying judge or agency simply attests to the fact that a qualifying act was committed against the victim, and that the victim was or likely would be cooperative. USCIS makes the ultimate determination on whether the victim qualifies, but without the family court or child protection agency certification the application is incomplete and cannot even be considered.

There are notable differences among the pre-requisite findings sought in SIJ, VAWA and U visas, as well as in the procedures used to procure them. The pre-requisite findings for SIJ applications, for example, must be issued by a family court judge, and are typically sought through written motions and/or hearings. In contrast, a $U$ visa certification can be issued by a wide variety of individuals, though family court judges and child protection agencies may often be in the best position to do so, and are often sought outside the courtroom. And whereas U visas and SIJ status cannot be granted without the pre-requisite findings, an immigrant's petition for VAWA relief can be granted without a court-issued order of protection, though it is a much more difficult route. As the next section of this essay explains, however, these differences do not affect family court lawyers' duties to advise clients that these findings are available, and to procure them if the client wishes.

Table 1: Types of Immigration Relief Which Rely on Family Court Findings

\begin{tabular}{|l|l|l|l|}
\hline $\begin{array}{l}\text { Form of Immigration } \\
\text { Relief }\end{array}$ & $\begin{array}{l}\text { Findings which can be } \\
\text { procured in family court to } \\
\text { assist with obtaining }\end{array}$ & $\begin{array}{l}\text { Conditions which } \\
\text { must be met to } \\
\text { obtain findings. }\end{array}$ & $\begin{array}{l}\text { Non-Exhaustive } \\
\text { list of } \\
\text { proceedings }\end{array}$ \\
\hline
\end{tabular}




\begin{tabular}{|c|c|c|c|}
\hline & immigration relief. & & $\begin{array}{l}\text { where findings } \\
\text { may be sought }\end{array}$ \\
\hline $\begin{array}{l}\text { Special Immigrant Juvenile } \\
\text { (SIJ) Status }\end{array}$ & $\begin{array}{l}\text { The predicate Special } \\
\text { Findings Order needed for a } \\
\text { youth to obtain SIJ status. }\end{array}$ & $\begin{array}{l}\text { Lawyer must } \\
\text { make showing to } \\
\text { judge that } \\
\text { immigrant youth } \\
\text { meets the five SIJ } \\
\text { requirements. }\end{array}$ & $\begin{array}{l}\text { Dependency } \\
\text { Termination of } \\
\text { Parental Rights } \\
\text { Guardianship } \\
\text { Adoption } \\
\text { Family Offense } \\
\text { Juvenile } \\
\text { Delinquency } \\
\text { Person in Need of } \\
\text { Supervision } \\
\text { Destitute Child }\end{array}$ \\
\hline $\begin{array}{l}\text { Violence Against Women } \\
\text { Act }\end{array}$ & $\begin{array}{l}\text { Final Order of Protection. } \\
\text { Temporary Order of } \\
\text { Protection. } \\
\text { (Note that these orders are } \\
\text { not required to obtain } \\
\text { VAWA relief, but are a } \\
\text { highly persuasive form of } \\
\text { proof of battery or extreme } \\
\text { cruelty). }{ }^{45}\end{array}$ & $\begin{array}{l}\text { Order of } \\
\text { Protection must be } \\
\text { granted to } \\
\text { immigrant youth } \\
\text { or adult by judge } \\
\text { after hearing or } \\
\text { upon consent of } \\
\text { respondent. }\end{array}$ & $\begin{array}{l}\text { Dependency } \\
\text { Family Offense } \\
\text { Person in Need of } \\
\text { Supervision } \\
\text { Destitute Child }\end{array}$ \\
\hline U Visa & Certification of cooperation. & $\begin{array}{l}\text { Immigrant youth } \\
\text { or adult must } \\
\text { assist judge, } \\
\text { prosecutor, police } \\
\text { or child protection } \\
\text { agency in } \\
\text { investigating or } \\
\text { prosecuting } \\
\text { qualifying crime. }\end{array}$ & $\begin{array}{l}\text { Dependency } \\
\text { Family Offense } \\
\text { Juvenile } \\
\text { Delinquency } \\
\text { Person in Need of } \\
\text { Supervision } \\
\text { Destitute Child }\end{array}$ \\
\hline
\end{tabular}

\section{The Collateral Mandate and SIJ, VAWA and U Visa Findings}

In determining how the duty to advise and advocate regarding collateral benefits applies to procuring those findings described above, the crucial question is whether obtaining the findings constitutes an objective that directly affects either a substantive right of the client or the ultimate

\footnotetext{
${ }^{45}$ In addition, if a VAWA petition to CIS does indicate that a petition for an order of protection has been filed, the failure to actually obtain the order will be extremely detrimental to the application.
} 
resolution of the case. ${ }^{46}$ It plainly affects both, and lawyers for immigrant survivors consequently have an ethical duty to advise their clients of this possible objective of the representation, and then to pursue that objective if the client wishes.

In Padilla v. Kentucky, ${ }^{47}$ the Supreme Court recognized that preserving the possibility of immigration relief could be of paramount importance to a client - possibly of even greater magnitude than avoiding incarceration - even in a non-immigration legal matter. ${ }^{48}$ The Court relied on an established "right to remain in the United States" as a primary basis for the ruling that criminal defense attorneys are constitutionally required to advise clients of possible deportation consequences to criminal convictions. ${ }^{49}$ Procuring findings in family court to preserve access to immigration relief, and consequently protect the right to remain in the United States, may similarly be of even greater importance to a client than the outcome of a family court matter itself. The consequences of being unauthorized are far-reaching for individuals and families. Unauthorized immigrants are not able to procure legal employment; are extremely unlikely to have health insurance; and are at constant risk of deportation and, consequently, exploitation. ${ }^{50}$ Unauthorized immigrants also tend to have attained lower levels of education in comparison to the general population; work at less stable employment; have lower incomes; have a higher rate of poverty; and be more likely to lack health insurance than those with legal status. ${ }^{51}$ And, as noted above, lack of legal status makes parents and children more susceptible to detentions and deportations that will

\footnotetext{
${ }^{46}$ See supra notes 11 to 21 and accompanying text for a more detailed explanation of this articulation of the duty.

${ }^{47} 130$ S. Ct. 1473 (2010).

${ }^{48}$ Padilla, 130 S. Ct. at 1484 (citing INS v. St. Cyr., 533 U.S. 289, 323, 121 S.Ct. 2271 (2001)).

${ }^{49} \mathrm{Id}$.

${ }^{50}$ See Jeffrey Passel, Unauthorized Migrants: Numbers And Characteristics 22, 26, 30, 34, 35 (Pew Hispanic Center 2005), available at http://pewhispanic.org/files/reports/46.pdf.

${ }^{51}$ ID.
} 
separate them legally and geographically. ${ }^{52}$ For many clients, these essential matters may carry far greater weight than the specific resolution of the case in family court.

The link between immigration status and the ultimate resolution of a family court matter itself is equally clear. The resolution of family court cases typically depends on the court's assessment of what will best serve a child's safety and well-being and promote permanency in the family. ${ }^{53}$ Immigration status directly impacts the resolution of these considerations in several ways. On a most concrete level, lack of lawful immigration status can result in the dramatic disruption of families, which obviously affects those goals. There are over five million children in the United States who have an unauthorized parent ${ }^{54}$ and whose families are consequently at constant risk of deportation and separation. In the first half of 2011 alone, the federal government deported more than 46,000 parents of U.S. citizen children, placing families at serious risk of long-term and even permanent separation. ${ }^{55}$ In addition, children of deported mothers often are forced to remain with perpetrators of domestic violence; long periods of detention by Immigration and Customs Enforcement exclude parents from participating in family decision-making; and prolonged separation due to detention and deportation traumatizes both children and parents. ${ }^{56}$ In family offense matters, where the ultimate legal objective is ending family violence and disruption, ${ }^{57}$ immigration status is a particularly critical factor to the ultimate resolution of a case. Abusers

\footnotetext{
${ }^{52}$ See supra notes 2 through 5.

${ }^{53}$ See, e.g., N.Y. FAM. CT. АСТ $\S 1011,1086$ (McKinney 2011)(purposes of family court proceedings include to "help protect children from injury or mistreatment and to help safeguard their physical, mental, and emotional well being," as well as to promote "permanency, safety and well-being."); N.Y. SOC. SERV. L. §384-b(1)(a)(i) and (iii) (McKinney 2011)("it is desirable for children to grow up... in a permanent home" and "the state's first obligation is to help the family with services to prevent its break-up or to reunite it if the child has already left home").

${ }^{54}$ Passel, Jeffrey S. and Cohn, D’Vera, A PORTRAIT OF UNAUTHORIZED IMMIGRANTS IN THE United STATES (Pew Hispanic Center 2009).

${ }_{55}^{55}$ SHATTERED FAMILIES, supra note 2, at 11.

${ }^{56}$ ID. at $38-42$.

${ }^{57}$ See, e.g., N.Y. FAM. CT. АCT §812(2)(b) (McKinney 2011)(“a family court proceeding is a civil proceedings and is for the purpose of attempting to stop the violence, end the family disruption and obtain protection").
} 
frequently use their power over a spouse or child's immigration status to control and isolate her. ${ }^{58}$

A battered spouse or child is often deterred from taking action to protect herself because of the fear of deportation. Documented immigration status for a survivor creates less dependence on the abuser, and therefore a greater opportunity for the victim of the abuse to leave the relationship. ${ }^{59}$ The increased independence that comes from documented status strengthens the potential for ending common cycles of family violence and disruption, and obtaining pre-requisite immigration findings in family court can clearly be critical to the process. More generally, lack of status means that youth and families do not have access to numerous services and benefits that might promote family court goals. Their inability to procure legal employment and health insurance, their susceptibility to deportation, and their higher rates of poverty all interfere with family stability and well-being. ${ }^{60}$

Because both the right to remain in the United States, and the ultimate goals of family court representation, are affected by immigration status, family court practitioners are ethically required to advise their clients when procuring pre-requisite findings is available as an option, and to engage in vigorous advocacy to actually seek to procure the findings if the client wishes.

Table 2: Relation of Immigration Status to Family Court Goals

\begin{tabular}{|l|l|l|}
\hline $\begin{array}{l}\text { Family } \\
\text { Court Goal. }\end{array}$ & How immigration status relates to goal of proceeding. & $\begin{array}{l}\text { Type(s) of } \\
\text { Proceeding }\end{array}$ \\
\hline Child's & Documented immigration status confers access to services & Dependency \\
\hline
\end{tabular}

${ }^{58}$ Preparing the VAWA Self-petition, supra note 31, at 2.

${ }^{59}$ See Leslye E. Orloff, et al., With No Place to Turn: Improving Legal Advocacy for Battered Women, 29 FAM. L.Q. 313, 314 (1995)(discussing how undocumented victims of domestic abuse are frequently culturally isolated and reluctant to leave abuser or seek legal assistance); Mary Ann Dutton et al., Characteristics of Help-Seeking Behaviors, Resources and Service Needs of Battered Immigrant Latinas: Legal and Policy Implications, 7 GEO. J. ON POVERTY L. \& POL'Y 245, 293 (2000)(noting that threats of deportation are very powerful tools used by abusers of immigrant women to keep them in abusive relationships and prevent them from seeking help).

${ }^{60}$ See UNAUTHORIZED MigRANTS supra note 50. 


\begin{tabular}{|l|l|l|}
\hline $\begin{array}{l}\text { permanency, } \\
\text { safety and } \\
\text { well-being. }\end{array}$ & $\begin{array}{l}\text { and benefits that promote permanency, safety and well- } \\
\text { being. } \\
\text { Permanent legal status permits child to reside indefinitely } \\
\text { in the United States, avoiding the disruption and traumatic } \\
\text { effects of deportation. }\end{array}$ & $\begin{array}{l}\text { Termination } \\
\text { of Parental } \\
\text { Rights } \\
\text { Guardianship } \\
\text { Custody }\end{array}$ \\
\hline $\begin{array}{l}\text { Ending } \\
\text { violence and } \\
\text { family } \\
\text { disruption. }\end{array}$ & $\begin{array}{l}\text { Documented immigration status for survivor reduces } \\
\text { dependency on abuser, creating greater opportunity for } \\
\text { survivor to leave violent relationship. } \\
\text { Documented immigration status for survivor and children } \\
\text { reduces chance that immigration status will result in family } \\
\text { disruption through deportation or detention of survivor and } \\
\text { children. }\end{array}$ & $\begin{array}{l}\text { Family } \\
\text { Offense }\end{array}$ \\
\hline
\end{tabular}

\section{Ramifications of the “Collateral Benefits” Mandate for Family Court Lawyers}

A requirement that lawyers counsel their family court clients and advocate on their behalf with regard to procuring findings that support SIJ, VAWA and U visa applications does carry ramifications for lawyers. Most significantly, it means that lawyers must be competent to counsel and advocate regarding those findings, attain that competence through training and study, or consult with or refer the matter to another lawyer. ${ }^{62}$ Fortunately, while these additional representational duties open the door to life-changing benefits for clients, they are nevertheless relatively uncomplicated for lawyers with respect to both client counseling and advocacy responsibilities. In fact, they require knowledge of legal standards and skills with which family court practitioners are already familiar.

In order to represent clients ethically, lawyers must understand how pre-requisite findings can assist in obtaining immigration relief, and lawyers must possess sufficient knowledge and skill to procure them. ${ }^{63}$ Generally, lawyers are required to explain a matter to the extent reasonably

\footnotetext{
${ }^{61}$ Unlike U.S. Citizenship, however, permanent legal status does not protect immigrants against deportation for committing certain criminal acts.

${ }^{62}$ Model RULeS OF PROF’L CONDUCT R 1.1, cmt. 1 (1983).

${ }^{63}$ ID. R. 1.1
} 
necessary to permit a client to make informed decisions. ${ }^{64}$ They must provide information and advice concerning material advantages and disadvantages of a proposed course of conduct, and discuss the client's options and alternatives. ${ }^{65}$ Family court lawyers, therefore, are required to inform their clients of any findings that can be procured that may assist in obtaining immigrationrelated relief, along with the advantages and disadvantages of obtaining them. There are, unsurprisingly, very few potential disadvantages to pursuing the findings in family court. The typical worst outcome is simply a denial of the lawyer's application for the findings. ${ }^{66}$ While a denial has grave consequences for the client, it leaves the client in no worse a position than before the application was made. The one notable exception is that the issuance of an order of protection can lead to the deportation of the abuser, which may not always be the resolution that best serves the family's interests and needs. This is, however, a straightforward consideration for an attorney to raise, though of course it may well complicate the client's own determination of whether to pursue the order, especially if she has already filed a VAWA application in which she stated that an order is being sought.

Because of the complexities and extreme consequences inherent in immigration law practice, most family court practitioners will not have the expertise to advise clients on whether or not to seek the immigration relief itself, ${ }^{67}$ but the competency duty does not require that level of expertise; in fact, it suggests that a lawyer should refer clients to an expert if the area of practice is

\footnotetext{
${ }^{64}$ ID. R. 1.4(b).

${ }^{65}$ ID. R. $1.0(\mathrm{q})$.

66 There are, however, some isolated incidences of family court judges calling Immigration and Customs Enforcement officials when an unauthorized immigrant appears before him. See, e.g., Associated Press, Judge Accused of Abusing Power by Reporting Immigrant Children; Judge Roger B. Colton Has Come Under Fire for Reporting Children that Appear in His Courtroom to Immigration Officials, The Miami Herald, Jan. 19, 2004, 2004 WL 56366842. Obviously, this should factor into the advice given to a client in such a jurisdiction.

${ }^{67}$ Richard A. Boswell, ESSENTIALS OF IMMIGRATION LAW 1 (2006)( "Mastering the subject matter of immigration law is more difficult than other areas of law... Immigration law is a patchwork of promulgations..."); see also Padilla, 130 S.Ct. 1473, 1483 ("Immigration law can be complex, and it is a legal specialty of its own.").
} 
sufficiently highly specialized. ${ }^{68}$ While family court practitioners usually will not have the expertise to pursue immigration relief on behalf of their clients, procuring the family court findings necessary for the immigration relief does fall squarely in the level of competency required of them. ${ }^{69}$ Not only is the potential family court role in these laws clear, but obtaining the relevant documentation involves issues that are consistent with legal standards and considerations that already are made in many typical family court proceedings. ${ }^{70}$ In SIJ cases, for example, family reunification and a child's best interests are findings that establish eligibility for relief; both those determinations are made regularly in dependency, adoption, guardianship and other proceedings, and lawyers in family court already must be extensively familiar with the procedural and substantive bases for making arguments related to both of those issues. For VAWA cases, procuring an Order of Protection is the objective of the representation anyway; the lawyer must simply also advise the client, as she decides whether to pursue the matter, of the potential immigration relief that exists if an Order is obtained, as well as the potential deportation consequences to the abuser. For $U$ visa cases, where a form certification must be signed, the lawyer simply must explain its potential benefit to the judge, police officer or child protection official whose signature is being sought. The basic argument that the certification will serve the well-being and permanency of the youth or family by removing the specter of deportation again coincides with

\footnotetext{
${ }^{68}$ Model Rules of PROF’L CONDUCT R 1.1, cmt. 1 (1983).

${ }^{69}$ MODEL RULES OF PROF’L CONDUCT R 1.1, cmt. 2 (1983)(“A lawyer need not necessarily have special training or prior experience to handle legal problems of a type with which the lawyer is unfamiliar... Some important legal skills... are required in all legal problems. Perhaps the most fundamental legal skill consists of determining what kind of legal problems a situation may involve."). ID R. 1.1, cmt. 4 ("A lawyer may accept representation where the requisite level of competence can be achieved by reasonable preparation. This applies as well to a lawyer who is appointed as counsel for an unrepresented person.”)(emphasis added).

70 This is not to say that many family courts may be unfamiliar with their role in providing necessary pre-requisite findings. See David B. Thronson, Of Borders and Best Interests: Examining the Experiences of Undocumented Immigrants in U.S. Family Courts, 11 TEX. HISP. J.L. \& POL'Y 45 (2005)(describing common judicial reactions when immigration-related matters arise in family couerts).
} 
the type of advocacy already typical for family court layers.

The ability to counsel clients and procure documentation related to immigration benefits for survivors is also consistent with other professional guidelines. The ABA's Model Act governing the representation of children in dependency cases specifically states that ancillary issues which lawyers should consider pursuing include immigration matters.. ${ }^{71}$ Some states even require attorneys representing children to obtain the necessary family court order for SIJ-eligible clients, and to refer them to appropriate immigration resources to pursue SIJ relief. ${ }^{72}$ Florida actually requires the child protection agency to obtain the special findings when appropriate, and to either handle pursuit the SIJ relief with immigration authorities or to refer to an appropriate legal service provider. $^{73}$

Ultimately, while obtaining the pre-requisite findings for each of these forms of relief may require overcoming barriers such as the court system's wariness or unfamiliarity with pre-requisite findings, those are barriers with which lawyers must regularly contend, and which they regularly seek to overcome through informed and vigorous advocacy.

\section{Conclusion}

As the number of authorized and unauthorized immigrants in the United States continues to rise ${ }^{74}$ immigration issues increasingly permeate family court proceedings. Unlike criminal

\footnotetext{
${ }^{71}$ Section of Litigation, Am Bar. Ass'N, Model Act Governing the RePresentation of Children in AbUSE, NEGLECT, AND DEPENDENCY PROCEEDINGS, Section 7, Commentary (2011).

72 N.Y.S. BAR ASS'N, COMM. ON CHILDREN \& THE LAW, STANDARDS FOR ATTORNEYS REPRESENTING CHILDREN IN New York Child Protective, Foster Care, and Termination of Parental Rights Proceedings, Standard C-7 (2007).

73 FLA. STAT. ANN. §39.5075 (2005).

${ }^{74}$ Randall Monger \& James Yankay, DePartment of Homeland SECURITY OfFICE OF IMMIGRATION STATISTICS, ANNUAL FlOW REPORT: U.S. LEGAL PERMANENT RESIDENTS: 2010 (March 2011)(over one million new immigrants obtained permanent legal status in 2010); Michael Hoffer, et al., DEPARTMENT OF HOMELAND SECURITY OfFICE OF
} 
proceedings, where that permeation leads only to devastating collateral immigration consequences, in family court it also creates opportunities for client counseling and advocacy that can lead to positive immigration outcomes. As described in this essay, certain vital avenues of immigration relief available to survivors of family crisis explicitly depend on findings, orders and certifications that are issued in the context of family court proceedings. For immigrant survivors of family crisis, the interplay between immigration law and family court proceedings therefore actually carries with it the opportunity to gain access to life-changing, and even life-saving, benefits. An understanding of these opportunities is essential for family court practitioners because family courts provide the primary legal forum for the protection of survivors of familial crisis; because of the family court's overarching purposes to promote safety, well-being and permanency for families and children; and because seizing these opportunities can lead to such dramatic benefits for children and families. But even more than that, it is required because lawyers in family court are ethically obligated to provide counseling and advocacy related to those opportunities. Unfortunately, while informing clients about these findings, and pursuing them when appropriate, clearly falls under the scope of a lawyer's ethical duties to counsel and advocate on behalf of her clients, the extent to which family court lawyers actually advise clients on the availability of those findings, and advocate in court to procure them, is remarkably inconsistent. ${ }^{75}$ A recognition that it is the ethical duty of the family court practitioner to engage in vigorous and effective counseling and advocacy for immigrant

\footnotetext{
IMMIGRATION STATISTICS, POPULATION ESTIMATES: ESTIMATES OF UNAUTHORIZED IMMIGRANT POPULATION RESIDING IN THE UNITED STATES: JANUARY 2010 (February 2011)(population of unauthorized immigrants in 2010 estimated at nearly 11 million). In particular, the number of immigrant youth who are abandoned, neglected or destitute - conditions that are typical of those addressed in family court - has surged recently. From October 2011 through March 2012, over five thousand unauthorized immigrant children came into U.S. custody without a parent or guardian - a 93 percent increase from the same period the previous year. Associated Press, Unprecedented surge in unaccompanied child immigrants puts stress on federal support system, Washington Post, 4/28/12.

${ }^{75}$ See Randi Mandelbaum \& Elissa Steglich, Disparate Outcomes: The Quest for Uniform Treatment of Immigrant Children, _ FAM. CT. REV. _ (2012).
} 
clients when opportunities to pursue immigration-related findings arise in the course of family court representation can lead more lawyers to seize those opportunities. 